\title{
Paenibacillus sophorae sp. nov., a nitrogen-fixing species isolated from the rhizosphere of Sophora japonica
}

\author{
Correspondence \\ San-Feng Chen \\ chensf@cau.edu.cn
}

\author{
Hao-Jie Jin, Jing Lv and San-Feng Chen
}

\author{
State Key Laboratory for Agrobiotechnology, China Agricultural University, Beijing 100193, PR \\ China
}

\begin{abstract}
A nitrogen-fixing bacterium, designated strain $S 27^{\top}$, was isolated from rhizosphere soil of Sophora japonica. Phylogenetic analysis based on a fragment of the nifH gene and the full-length $16 \mathrm{~S}$ rRNA gene sequence revealed that strain $S 27^{\top}$ is a member of the genus Paenibacillus. High levels of $16 \mathrm{~S}$ rRNA gene sequence similarity were found between strain $S 27^{\top}$ and Paenibacillus durus DSM $1735^{\top}(97.3 \%)$, Paenibacillus sabinae DSM $17841^{\top}(96.9 \%)$, Paenibacillus forsythiae DSM $17842^{\top}(96.7 \%)$ and Paenibacillus zanthoxyli DSM $18202^{\top}$ (96.6\%). However, DNA-DNA hybridization values between strain $S 27^{\top}$ and the four type strains were $37.64 \%$, $23.12 \%, 25.6 \%$ and $34.99 \%$, respectively. Levels of $16 \mathrm{~S}$ rRNA gene sequence similarity between strain $S 27^{\top}$ and the type strains of other recognized members of the genus Paenibacillus were below $96.5 \%$. The DNA G $+C$ content of strain $S 27^{\top}$ was 46.0 mol\%. The major fatty acids were anteiso- $C_{15: 0}, C_{16: 0}$ and iso- $C_{16: 0}$. The major isoprenoid quinone was MK-7. On the basis of its phenotypic characteristics and DNA-DNA hybridization results, strain $S 27^{\top}$ is considered to represent a novel species of the genus Paenibacillus, for which the name Paenibacillus sophorae sp. nov. is proposed. The type strain is $S 27^{\top}\left(=\right.$ CGMCC $1.10238^{\top}=$ DSM $\left.23020^{\top}\right)$.
\end{abstract}

The genus Paenibacillus was described by Ash et al. (1993) on the basis of analysis of the 16S rRNA gene sequences of group 3 bacilli. Members of the genus are widely distributed in nature and have diverse physiological characteristics. Some species consistently show a great capacity to fix atmospheric nitrogen in vitro (Elo et al., 2001; Berge et al., 2002; Ding et al., 2005; Ma et al., 2007a, b). At the time of writing, there are more than 100 species in this genus, including 16 species having nitrogen-fixing ability. These are Paenibacillus polymyxa, $P$. macerans, $P$. peoriae, $P$. graminis, $P$. odorifer, $P$. brasilensis, $P$. azotofixans, $P$. borealis, $P$. wynnii, $P$. massiliensis, $P$. sabinae, $P$. zanthoxyli, 'P. donghaensis', $P$. forsythiae, P. riograndensis and P. sonchi (Beneduzi et al., 2010; Coelho et al., 2009; Hong et al., 2009). Here we show that a bacterial strain, designated $\mathrm{S} 27^{\mathrm{T}}$, isolated from rhizosphere soil of Sophora japonica represents a novel nitrogen-fixing species of the genus Paenibacillus.

Strain $\mathrm{S} 27^{\mathrm{T}}$ was isolated from rhizosphere soil of Sophora japonica from Fenghuang mountain $\left(39^{\circ} 54^{\prime} \mathrm{N} 116^{\circ} 23^{\prime} \mathrm{E}\right.$ ) in the north-west of Beijing, People's Republic of China.

The GenBank/EMBL/DDBJ accession numbers for the $16 \mathrm{~S}$ rRNA and nifH gene sequences of strain $\mathrm{S} 27^{\top}$ are G0.985395 and G0.985394, respectively.

Five supplementary figures are available with the online version of this paper.
Soil was collected at a depth of $30 \mathrm{~cm}$ below ground near the plant root then transported to the lab as soon as possible. The soil sample was placed in $9 \mathrm{ml}$ sterile water and stirred for $30 \mathrm{~min}$. The aqueous portion $(100 \mu \mathrm{l})$ was heated at $80{ }^{\circ} \mathrm{C}$ for $15 \mathrm{~min}$ and then spread on nitrogenfree medium (Ma et al., 2007a, b) in triplicate and incubated at $30{ }^{\circ} \mathrm{C}$. After 3 days of incubation, strain $\mathrm{S} 27^{\mathrm{T}}$ was selected for further study. Strain $S 27^{\mathrm{T}}$ was the only isolate with nitrogen-fixing ability found in this habitat.

To confirm the nitrogen-fixing capacity of strain $S 27^{\mathrm{T}}$, an assay for nitrogenase activity and PCR amplification of the nifH gene were carried out. For measurement of nitrogenase activity, strain $\mathrm{S} 27^{\mathrm{T}}$ and several reference strains were incubated on solid RCV mineral medium containing $2 \%$ glucose (Weaver et al., 1975). After $48 \mathrm{~h}$ of incubation at $30{ }^{\circ} \mathrm{C}$, strains were incubated under $2 \%(\mathrm{v} / \mathrm{v})$ acetylene in air for $2 \mathrm{~h}$, and were then analysed for ethylene production by HP6890 gas chromatography (Berge et al., 2002). As shown in Table 1, strain $\mathrm{S} 27^{\mathrm{T}}$ exhibited nitrogenase activity.

Whole-cell DNA for PCR amplification was extracted according to standard methods (Sambrook et al., 1989). A 325 bp fragment of the nifH gene was amplified by using two degenerate primers for the nitrogenase Fe protein gene and then sequenced as described by Ding et al. (2005). Phylogenetic trees were inferred using the neighbourjoining method and the maximum-parsimony method in 
Table 1. Nitrogenase activity of strain $S 27^{\top}$ compared with some nitrogen-fixing species of the genus Paenibacillus

Results are means $\underline{ \pm S D}$ of three determinations.

\begin{tabular}{|c|c|}
\hline Strain & $\begin{array}{l}\text { Nitrogenase activity } \\
{\left[\text { nmol } \mathrm{C}_{2} \mathrm{H}_{4}\right.} \\
\left.(\mathrm{mg} \text { protein })^{-1} \mathbf{h}^{-1}\right]\end{array}$ \\
\hline P. durus ATCC 35681 & $1623 \pm 89.4$ \\
\hline P. zanthoxyli DSM $18202^{\mathrm{T}}$ & $4326 \pm 127.8$ \\
\hline P. sabinae DSM $17841^{\mathrm{T}}$ & $287 \pm 73.5$ \\
\hline P. forsythiae DSM $17842^{\mathrm{T}}$ & $268 \pm 55.4$ \\
\hline P. odorifer TOD $45^{\mathrm{T}}$ & $13.4 \pm 1.33$ \\
\hline P. polymyxa ATCC $842^{\mathrm{T}}$ & $8.74 \pm 0.84$ \\
\hline P. graminis $\mathrm{RSA} 19^{\mathrm{T}}$ & $183.5 \pm 33.7$ \\
\hline $\mathrm{S} 27^{\mathrm{T}}$ & $232.3 \pm 43.1$ \\
\hline
\end{tabular}

the software package MEGA3.1 (Kumar \& Tamura, 2004). No significant differences were found among the phylogenetic trees reconstructed by these two different methods. Phylogenetic analysis based on nifH gene sequence revealed that strain $S 27^{\mathrm{T}}$ clustered with species of the genus Paenibacillus (Fig. 1 and Supplementary Fig. S1, available in IJSEM Online). Levels of nifH gene sequence similarity between strain $\mathrm{S} 27^{\mathrm{T}}$ and $P$. forsythiae, P. zanthoxyli, $P$. durus and $P$. sabinae were $96.9 \%, 96.3 \%, 95.1 \%$ and $79.6 \%$, respectively.

A nearly complete sequence of the $16 \mathrm{~S}$ rRNA gene (1463 bp) was obtained from a PCR product amplified from strain $S 27^{\mathrm{T}}$ by using the universal forward primer $\mathrm{P} 1$ and the universal reverse primer $\mathrm{P} 6$. Primer P1 (5'-AGAGTTTGATCCTGGTCAGAACGCT-3') corresponds to positions 8-37 and primer P6 (5'-TACGGCTACCTTGTTACGACTTCACCCC-3') corresponds to positions 1479-1506 in the Escherichia coli 16S rRNA gene (Yanagi \& Yamasato, 1993). The amplified 16S rRNA gene was sequenced by using an ABI377 automatic sequencer (Applied Biosystems). Comparison of the 16S rRNA gene sequence of strain $S 27^{\mathrm{T}}$ with sequences held in GenBank revealed that this organism clustered with species of the genus Paenibacillus. The $16 \mathrm{~S}$ rRNA gene sequence of strain $\mathrm{S} 27^{\mathrm{T}}$ was aligned with sequences of recognized species of the genus Paenibacillus by using the software package MEGA3.1 (Fig. 2 and Supplementary Fig. S2). An extended version of this tree is available as Supplementary Fig. S3. Strain S27 ${ }^{\mathrm{T}}$ showed high $16 \mathrm{~S}$ rRNA gene sequence similarities with $P$. durus DSM $1735^{\mathrm{T}}$ (97.3\%), P. sabinae DSM $17841^{\mathrm{T}}$ (96.9\%), P. forsythiae DSM $17842^{\mathrm{T}}(96.7 \%)$ and P. zanthoxyli DSM $18202^{\mathrm{T}}(96.6 \%)$. Levels of $16 \mathrm{~S}$ rRNA gene sequence similarity between strain $S 27^{\mathrm{T}}$ and other recognized members of the genus Paenibacillus were below $96.5 \%$.

Strains belonging to the genus Paenibacillus are often identified by PCR amplification of a $16 \mathrm{~S}$ rRNA gene fragment with the highly specific forward primer PAEN515F (5'-GCTCGGAGAGTGACGGTACCTGAGA$3^{\prime}$ ) (Shida et al., 1997) and universal reverse primer 1377R (5'-GGCATGCTGATCCGCGATTACTAGC3') (Shida et al., 1996). A 900 bp fragment was PCRamplified from strain $\mathrm{S} 27^{\mathrm{T}}$ when the Paenibacillus specific primers PAEN515F and 1377R were used in this study. The result further suggested that strain $\mathrm{S} 27^{\mathrm{T}}$ was a member of the genus Paenibacillus.

Strain $S 27^{\mathrm{T}}$ was tested for a range of phenotypic, physiological and biochemical characteristics together with the type strains of closely related species of the genus Paenibacillus, including $P$. durus DSM $1735^{\mathrm{T}}, P$. sabinae DSM $17841^{\mathrm{T}}$, P. forsythiae DSM $17842^{\mathrm{T}}$, P. zanthoxyli DSM $18202^{\mathrm{T}}$ and $P$. stellifer DSM $14472^{\mathrm{T}}$. For observation of cell morphology, strain $\mathrm{S} 27^{\mathrm{T}}$ was incubated on endosporeforming medium $\left[1^{-1}: 0.07 \%\right.$ yeast extract, $0.1 \%$ tryptone, $0.1 \%$ glucose, $0.02 \%\left(\mathrm{NH}_{4}\right)_{2} \mathrm{SO}_{4}, 0.02 \% \mathrm{MgSO}_{4} .7 \mathrm{H}_{2} \mathrm{O}$ and $\left.0.1 \% \mathrm{~K}_{2} \mathrm{HPO}_{4}, \mathrm{pH} 7.0\right]$ for $14 \mathrm{~h}$ and cells were then examined by scanning electron microscopy (Hitachi S3400). Strain $S 27^{\mathrm{T}}$ formed ellipsoidal spores, located centrally in swollen sporangia (Supplementary Fig. S4). Colonies on LD medium $\left(1^{-1}: 10 \mathrm{~g}\right.$ tryptone, $5 \mathrm{~g}$ yeast extract, $2.5 \mathrm{~g} \mathrm{NaCl}, \mathrm{pH} 6.0$ ) agar were circular, convex,

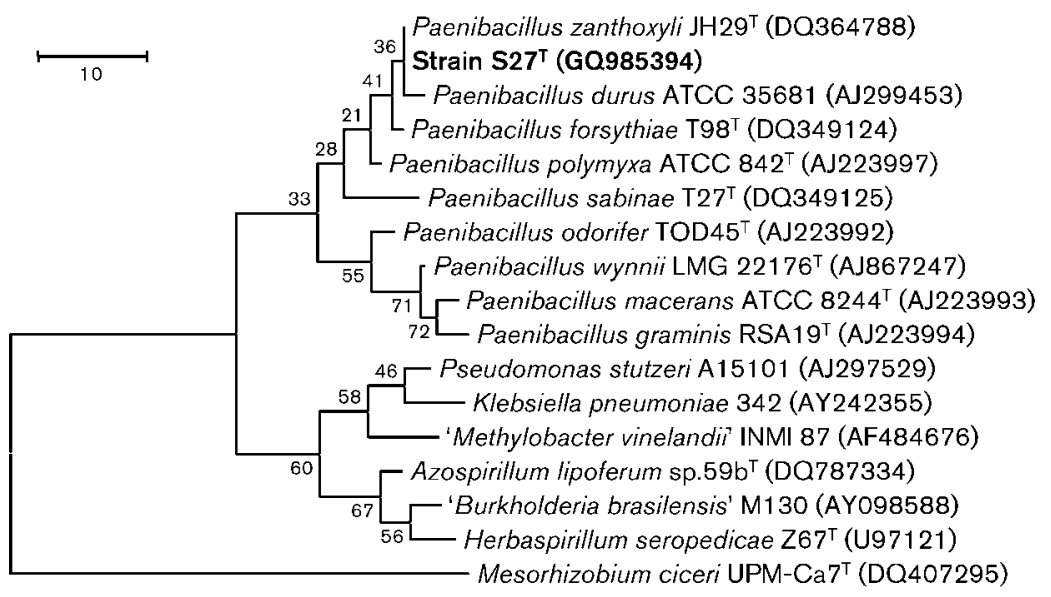

Fig. 1. Maximum-parsimony phylogenetic tree based on partial nifH gene sequence comparison (325 nt fragment), showing the position of strain $\mathrm{S} 27^{\top}$. Mesorhizobium ciceri UPM-Ca $7^{\top}$ was used as an outgroup. Bootstrap analyses were performed with 1000 replications (percentages are shown at branch points). Bar, 10 substitutions per nucleotide position. 


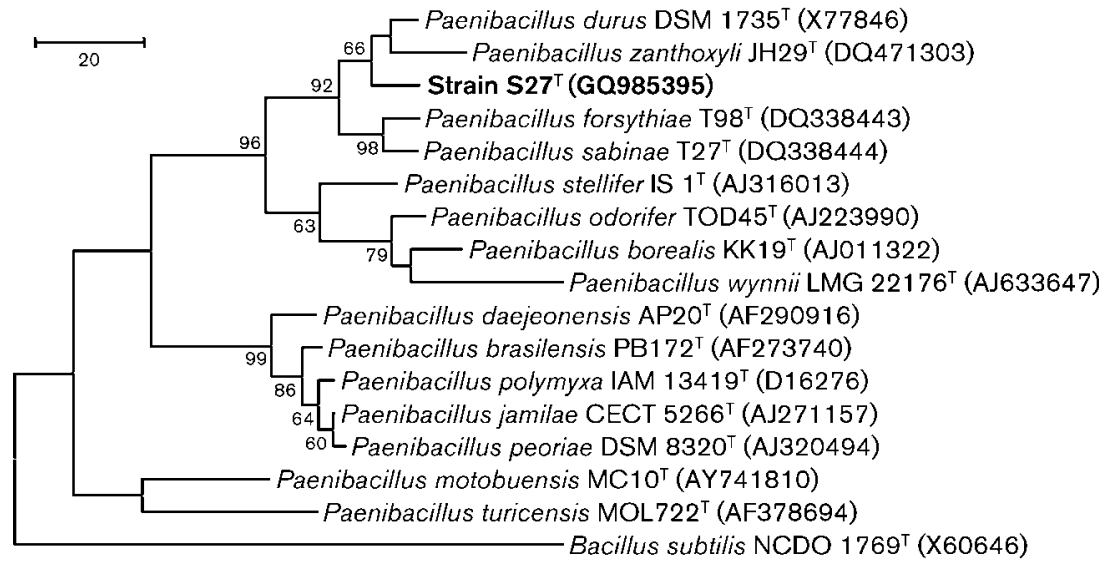

Fig. 2. Maximum-parsimony phylogenetic tree based on 16S rRNA gene sequences showing the position of strain $S 27^{\top}$ among species of the genus Paenibacillus. Bacillus subtilis NCDO $1769^{\top}$ was used as an outgroup. Bootstrap analyses were performed with 1000 replications (percentages are shown at branch points). Bar, 20 substitutions per nucleotide position.

white and glossy with entire margins after $72 \mathrm{~h}$ of incubation at $30{ }^{\circ} \mathrm{C}$. Gram staining demonstrated that cells of strain $\mathrm{S} 27^{\mathrm{T}}$ were Gram-stain-positive rods. Cell motility was determined by observing the growth spread of cells in test tubes containing semi-solid LD medium after incubation for 3 days. From the spread morphology of the clone in the test tube, cells of strain $S 27^{\mathrm{T}}$ were identified as motile. To determine aerotactic ability, bacterial cells were incubated by mixing with semi-solid medium at $40-50{ }^{\circ} \mathrm{C}$ in test tubes followed by incubation at $30{ }^{\circ} \mathrm{C}$ for 3 days. Although cells of strain $\mathrm{S} 27^{\mathrm{T}}$ grew throughout the medium in test tubes, cells near the surface grew better than those near the bottom, suggesting that strain $S 27^{\mathrm{T}}$ was facultatively anaerobic.

Most physiological and biochemical tests, including Gram staining, nitrate reduction, production of dextrin, optimal temperature and $\mathrm{pH}$ for growth, activities of catalase and oxidase, Voges-Proskauer reaction and growth inhibition by $\mathrm{NaCl}$ and lysozyme were performed according to Gordon et al. (1973), Priest et al. (1981) and RhodesRoberts (1981). Hydrolysis of casein and starch was determined as described by Cowan \& Steel (1965). Utilization of various substrates as carbon and energy sources was determined as described by Shirling \& Gottlieb (1966). The physiological and biochemical characteristics of strain $S 27^{\mathrm{T}}$ compared with those of the type strains of closely related species of the genus Paenibacillus are presented in Table 2. As shown, strain $\mathrm{S} 27^{\mathrm{T}}$ has physiological properties that allow its distinction from these recognized species of the genus Paenibacillus.

The DNA G + C content was determined by the method of Tamaoka \& Komagata (1984). The DNA G + C content of strain $\mathrm{S} 27^{\mathrm{T}}$ was $46.0 \mathrm{~mol} \%$ (Table 2), which was within the range of values for recognized species of the genus Paenibacillus (Shida et al., 1997).

For DNA-DNA hybridization experiments, total genomic DNA was extracted and purified according to the method described by Yoon et al. (1996) with some modifications. DNA-DNA hybridization was performed according to the method of Ziemke et al. (1998). DNA-DNA hybridization values between strain $\mathrm{S} 27^{\mathrm{T}}$ and $P$. durus DSM $1735^{\mathrm{T}}, P$. sabinae DSM $17841^{\mathrm{T}}$, P. forsythiae DSM $17842^{\mathrm{T}}$ and $P$. zanthoxyli DSM $18202^{\mathrm{T}}$ were $37.64 \%, 23.12 \%, 25.6 \%$ and $34.99 \%$, respectively. According to the recommendations of Wayne et al. (1987), strain $S 27^{\mathrm{T}}$ and the four type strains did not belong to the same species as the value for DNA-DNA relatedness was lower than the threshold value of $70 \%$.

Table 2. Differential phenotypic characteristics between strain $S 27^{\top}$ and the type strains of its closest neighbours in the genus Paenibacillus

Strains: $1, \mathrm{~S}_{2} 7^{\mathrm{T}} ; 2$, P. durus DSM $1735^{\mathrm{T}} ; 3$, P. sabinae DSM $17841^{\mathrm{T}} ; 4$, P. forsythiae DSM $17842^{\mathrm{T}}$; 5, P. zanthoxyli DSM $18202^{\mathrm{T}} ; 6$, P. stellifer DSM $14472^{\mathrm{T}}$. + , Positive reaction; - , negative reaction.

\begin{tabular}{|lcccccc|}
\hline Characteristic & $\mathbf{1}$ & $\mathbf{2}$ & $\mathbf{3}$ & $\mathbf{4}$ & $\mathbf{5}$ & $\mathbf{6}$ \\
\hline Optimum growth temp. $\left({ }^{\circ} \mathrm{C}\right)$ & 30 & 30 & 30 & 30 & 30 & 28 \\
Growth in the presence of $3 \%$ & - & - & + & + & + & - \\
$\mathrm{NaCl}$ & & & & & & \\
Voges-Proskauer reaction & - & + & + & + & + & - \\
Nitrate reduction & + & - & + & + & + & - \\
Production of dextrin & - & + & - & - & - & + \\
Hydrolysis of: & & & & & & \\
Casein & - & - & - & + & - & - \\
Starch & - & + & - & - & - & + \\
Acid production from: & & & & & & \\
Maltose & + & + & - & - & - & + \\
Sucrose & - & + & - & - & - & + \\
D-Xylose & + & + & - & - & - & + \\
Sodium citrate & + & - & - & - & - & - \\
Sodium succinate & - & - & - & + & - & - \\
D-Fructose & - & - & - & - & - & + \\
D-Glucose & + & + & - & - & - & + \\
Glycerol & - & + & - & - & - & - \\
D-Sorbitol & + & + & - & - & - & - \\
Lactose & + & + & - & - & - & + \\
DNA G+C content $(\mathrm{mol} \%)$ & 46.0 & 50.3 & 51.8 & 50.1 & 54.3 & $55.6^{*}$ \\
& & & & & & \\
\hline
\end{tabular}

${ }^{\star}$ Data from Suominen et al. (2003). 
Cellular menaquinones were extracted and purified as described by Collins (1985) and were then analysed by HPLC. The menaquinone profile (MK-7 as the major component) was in agreement with the description of the genus Paenibacillus. Polar lipids extracted by the method of Minnikin et al. (1979) were identified by two-dimensional TLC and spraying with specific reagents as described by Collins et al. (1980). The major polar lipids presented in strain $\mathrm{S} 27^{\mathrm{T}}$ were diphosphatidylglycerol, phosphatidylglycerol and lyso-phosphatidylglycerol. Traces of phosphatidylinositol, phosphatidylinositol-methyl and phosphatidylinositol dimannoside were also detected (Supplementary Fig. S5). meso-Diaminopimelic acid as the diagnostic diamino acid in the cell wall was identified by TLC (Staneck \& Roberts, 1974). For determination of its cellular fatty acid composition, strain $S 27^{\mathrm{T}}$ was incubated in $\mathrm{LD}$ medium at $30{ }^{\circ} \mathrm{C}$ for 3 days. Analysis was carried out as described by Komagata \& Suzuki (1987) by using the Sherlock Identification System (MIDI; Sasser et al., 2005). Profiles of the major fatty acids of strain $\mathrm{S} 27^{\mathrm{T}}$ and the type strains of closely related members of the genus Paenibacillus are shown in Table 3. Anteiso- $\mathrm{C}_{15: 0}$, the major fatty acid in recognized members of the genus Paenibacillus, was also the major fatty acid component of strain $\mathrm{S} 27^{\mathrm{T}}(36.03 \%)$.

In summary, phylogenetic analysis based on the full-length $16 \mathrm{~S}$ rRNA gene sequence and the fragment of the nifH gene sequence, DNA G+C content and chemotaxonomic properties revealed that strain $S 27^{\mathrm{T}}$ was a member of the genus Paenibacillus. Several phenotypic characteristics and DNA-DNA hybridization further demonstrated that the isolated strain, $\mathrm{S} 27^{\mathrm{T}}$, represents a novel species of the genus Paenibacillus, for which the name Paenibacillus sophorae sp. nov. is proposed.

\section{Description of Paenibacillus sophorae sp. nov.}

Paenibacillus sophorae (so.pho'ra.e. N.L. gen. n. sophorae of Sophora, referring to the plant Sophora japonica, the source of the rhizosphere soil from which the type strain was isolated).

Cell are Gram-stain-positive, facultatively anaerobic, motile, straight rods, measuring 0.6-1.5 $\mu \mathrm{m} \times 1.5-3 \mu \mathrm{m}$. Ellipsoidal spores are located centrally in swollen sporangia. Colonies on LD medium are circular, convex, white and glossy with entire margins after $72 \mathrm{~h}$ of incubation at $30{ }^{\circ} \mathrm{C}$; usually they are 1-2 $\mathrm{mm}$ in diameter. The temperature range for growth is $15-50{ }^{\circ} \mathrm{C}$, with optimal growth at $30{ }^{\circ} \mathrm{C}$. The $\mathrm{pH}$ range for growth is $4-8$ (optimum $\mathrm{pH} 6.0$ ). Unable to tolerate $3 \%(\mathrm{w} /$ v) $\mathrm{NaCl}$. Growth is inhibited by $0.001 \%(\mathrm{w} / \mathrm{v})$ lysozyme. Catalase- and oxidase-negative. Negative for the VogesProskauer reaction. Nitrate can be reduced to nitrite. Nitrogen is fixed. The following substrates are utilized for growth and acid production: maltose, D-xylose, sodium citrate, D-glucose, lactose, D-sorbitol, raffinose, $N$-acetyl-Dglucosamine, glycogen, mannitol, trehalose, cellobiose, Dgalactose, L-sorbose and D-mannose. Acid is not produced
Table 3. Cellular fatty acid profiles of strain $S 27^{\top}$ and type strains of closely related species of the genus Paenibacillus

Strains: $1, \mathrm{~S}^{2} 7^{\mathrm{T}} ; 2$, P. durus DSM $1735^{\mathrm{T}} ; 3$, P. zanthoxyli DSM $18202^{\mathrm{T}} ; 4$, P. forsythiae DSM $17842^{\mathrm{T}} ; 5$, P. sabinae DSM $17841^{\mathrm{T}}$. Data are percentages of the total fatty acids. For unsaturated fatty acids, the position of the double bond can be located by counting from the methyl $(\omega)$ end of the carbon chain; cis isomers are indicated by the suffix $c$. Results were determined under the same conditions for all strains.

\begin{tabular}{|c|c|c|c|c|c|}
\hline Fatty acid & 1 & 2 & 3 & 4 & 5 \\
\hline \multicolumn{6}{|c|}{ Saturated straight-chain } \\
\hline $\mathrm{C}_{14: 0}$ & 5.37 & 4.76 & 4.84 & 4.79 & 2.93 \\
\hline $\mathrm{C}_{15: 0}$ & $<0.2$ & 1.33 & 2.15 & 1.94 & 1.55 \\
\hline $\mathrm{C}_{16: 0}$ & 26.85 & 19.87 & 12.88 & 18.59 & 18.07 \\
\hline $\mathrm{C}_{18: 0}$ & 1.58 & 5.48 & 6.77 & 5.73 & 3.24 \\
\hline \multicolumn{6}{|c|}{ Saturated iso-branched } \\
\hline iso- $\mathrm{C}_{14: 0}$ & 3.40 & 5.31 & 3.79 & 2.66 & 3.24 \\
\hline iso- $\mathrm{C}_{15: 0}$ & 4.20 & 7.98 & 1.63 & 0.99 & 1.40 \\
\hline iso- $\mathrm{C}_{16: 0}$ & 7.98 & 10.58 & 14.90 & 11.53 & 14.44 \\
\hline iso- $\mathrm{C}_{17: 0}$ & 1.12 & 1.48 & 0.59 & 0.95 & 0.82 \\
\hline \multicolumn{6}{|c|}{$\begin{array}{l}\text { Saturated anteiso- } \\
\text { branched }\end{array}$} \\
\hline anteiso- $\mathrm{C}_{15: 0}$ & 36.03 & 39.76 & 32.25 & 29.97 & 36.62 \\
\hline anteiso- $\mathrm{C}_{17: 0}$ & 3.24 & 1.94 & 3.87 & 4.61 & 6.34 \\
\hline \multicolumn{6}{|l|}{ Unsaturated } \\
\hline $\mathrm{C}_{18: 1} \omega 9 c$ & 0.96 & 2.12 & 1.54 & 4.83 & 3.85 \\
\hline
\end{tabular}

from sucrose, sodium succinate, D-fructose, glycerol, Laspartate, L-arabinose, sodium DL-malate, D-ribose, inositol, DL-malic acid, inulin or creatine. Cannot hydrolyse casein, starch or gelatin. The DNA G $+\mathrm{C}$ content of the type strain is $46.0 \mathrm{~mol} \%$ (thermal denaturation method). The cell wall contains meso-diaminopimelic acid. The predominant menaquinone is MK-7. The major fatty acids are anteiso$\mathrm{C}_{15: 0}, \mathrm{C}_{16: 0}$ and iso- $\mathrm{C}_{16: 0}$. Sensitive to ampicillin $(100 \mu \mathrm{g}$ $\left.\mathrm{ml}^{-1}\right)$, kanamycin $\left(50 \mu \mathrm{g} \mathrm{ml} \mathrm{m}^{-1}\right)$, streptomycin $(40 \mu \mathrm{g}$ $\left.\mathrm{ml}^{-1}\right)$, tetracycline $\left(12.5 \mu \mathrm{g} \mathrm{ml} \mathrm{g}^{-1}\right)$ and chloromycetin $\left(30 \mu \mathrm{g} \mathrm{ml}^{-1}\right)$ but resistant to spectinomycin $\left(100 \mu \mathrm{g} \mathrm{ml}^{-1}\right)$.

The type strain, $\mathrm{S} 27^{\mathrm{T}} \quad\left(=\mathrm{CGMCC} 1.10238^{\mathrm{T}}=\mathrm{DSM}\right.$ $23020^{\mathrm{T}}$ ), was isolated from rhizosphere soil of Sophora japonica planted in Beijing, China.

\section{Acknowledgements}

We are grateful to Professor Mirja Salkinoja-Salonen of Helsinki University for the gift of $P$. stellifer. We are also grateful for Dr R. Pukall's generous help when the strain was deposited in DSMZ. This work was supported by the National Natural Science Foundation of China (grant no. 30670036).

\section{References}

Ash, C., Priest, F. G. \& Collins, M. D. (1993). Molecular identification of rRNA group 3 bacilli (Ash, Farrow, Wallbanks and Collins) using a PCR probe test. Proposal for the creation of a new genus Paenibacillus. Antonie van Leeuwenhoek 64, 253-260. 
Beneduzi, A., Costa, P. B., Parma, M., Melo, I. S., Bodanese-Zanettini, M. H. \& Passaglia, L. M. (2010). Paenibacillus riograndensis sp. nov., a nitrogen-fixing species isolated from the rhizosphere of Triticum aestivum. Int J Syst Evol Microbiol 60, 128-133.

Berge, O., Guinebretière, M. H., Achouak, W., Normand, P. \& Heulin, T. (2002). Paenibacillus graminis sp. nov. and Paenibacillus odorifer sp. nov., isolated from plant roots, soil and food. Int J Syst Evol Microbiol 52, 607-616.

Coelho, M. R., Carneiro, N. P., Marriel, I. E. \& Seldin, L. (2009). Molecular detection of nifH gene-containing Paenibacillus in the rhizosphere of sorghum (Sorghum bicolor) sown in Cerrado soil. Lett Appl Microbiol 48, 611-617.

Collins, M. D. (1985). Analysis of isoprenoid quinones. Methods Microbiol 18, 329-366.

Collins, M. D., Goodfellow, M. \& Minnikin, D. E. (1980). Fatty acid, isoprenoid quinone and polar lipid composition in the classification of Curtobacterium and related taxa. J Gen Microbiol 118, 29-37.

Cowan, S. T. \& Steel, K. J. (1965). Manual for the Identification of Medical Bacteria. London: Cambridge University Press.

Ding, Y., Wang, J., Liu, Y. \& Chen, S. (2005). Isolation and identification of nitrogen-fixing bacilli from plant rhizospheres in Beijing region. J Appl Microbiol 99, 1271-1281.

Elo, S., Suominen, I., Kämpfer, P., Juhanoja, J., Salkinoja-Salonen, M. \& Haahtela, K. (2001). Paenibacillus borealis sp. nov., a nitrogen-fixing species isolated from spruce forest humus in Finland. Int J Syst Evol Microbiol 51, 535-545.

Gordon, R. E., Haynes, W. C. \& Pang, C. H.-N. (1973). The Genus Bacillus. US Department of Agriculture Handbook no. 427. Washington, DC: Agricultural Research Service.

Hong, Y. Y., Ma, Y. C., Zhou, Y. G., Gao, F., Liu, H. C. \& Chen, S. F. (2009). Paenibacillus sonchi sp. nov., a nitrogen-fixing species isolated from the rhizosphere of Sonchus oleraceus. Int J Syst Evol Microbiol 59, 2656-2661.

Komagata, K. \& Suzuki, K. (1987). Lipid and cell-wall analysis in bacterial systematics. Methods Microbiol 19, 161-207.

Kumar, S., Tamura, K. \& Nei, M. (2004). MEGA3: integrated software for molecular evolutionary genetics analysis and sequence alignment. Brief Bioinform 5, 150-163.

Ma, Y., Xia, Z., Liu, X. \& Chen, S. (2007a). Paenibacillus sabinae sp. nov., a nitrogen-fixing species isolated from the rhizosphere soils of shrubs. Int J Syst Evol Microbiol 57, 6-11.

Ma, Y., Zhang, J. \& Chen, S. (2007b). Paenibacillus zanthoxyli sp. nov., a novel nitrogen-fixing species isolated from the rhizosphere of Zanthoxylum simulans. Int J Syst Evol Microbiol 57, 873-877.

Minnikin, D. E., Collins, M. D. \& Goodfellow, M. (1979). Fatty acid and polar lipid composition in the classification of Cellulomonas, Oerskovia and related taxa. J Appl Bacteriol 47, 87-95.

Priest, F. G., Goodfellow, M. \& Todd, C. (1981). The genus Bacillus: a numerical analysis. In The Aerobic Endospore-Forming Bacteria.
Classification and Identification, pp. 91-103. Edited by R. C. W. Berkeley \& M. Goodfellow. London: Academic Press.

Rhodes-Roberts, M. (1981). The taxonomy of some nitrogen-fixing Bacillus species with special reference to nitrogen fixation. In The Aerobic Endospore-Forming Bacteria. Classification and Identification, pp. 315-335. Edited by R. C. W. Berkeley \& M. Goodfellow. London: Academic Press.

Sambrook, J., Fritsch, E. F. \& Maniatis, T. (1989). Molecular Cloning: a Laboratory Manual, 2nd edn. Cold Spring Harbor, NY: Cold Spring Harbor Laboratory Press.

Sasser, M., Kunitsky, C., Jackoway, G., Ezzell, J. W., Teska, J. D., Harper, B., Parker, S., Barden, D., Blair, H. \& other authors (2005). Identification of Bacillus anthracis from culture using gas chromatographic analysis of fatty acid methyl esters. J AOAC Int 88, 178-181.

Shida, O., Takagi, H., Kadowaki, K. \& Komagata, K. (1996). Proposal for two new genera, Brevibacillus gen. nov. and Aneurinibacillus gen. nov. Int J Syst Bacteriol 46, 939-946.

Shida, O., Takagi, H., Kadowaki, K., Nakamura, L. K. \& Komagata, K. (1997). Transfer of Bacillus alginolyticus, Bacillus chondroitinus, Bacillus curdlanolyticus, Bacillus glucanolyticus, Bacillus kobensis and Bacillus thiaminolyticus to the genus Paenibacillus and emended description of the genus Paenibacillus. Int J Syst Bacteriol 47, 289-298.

Shirling, E. B. \& Gottlieb, D. (1966). Methods for characterization of Streptomyces species. Int J Syst Bacteriol 16, 313-340.

Staneck, J. L. \& Roberts, G. D. (1974). Simplified approach to identification of aerobic actinomycetes by thin-layer chromatography. Appl Microbiol 28, 226-231.

Suominen, I., Spröer, C., Kämpfer, P., Rainey, F. A., Lounatmaa, K. \& Salkinoja-Salonen, M. (2003). Paenibacillus stellifer sp. nov., a cyclodextrin-producing species isolated from paperboard. Int J Syst Evol Microbiol 53, 1369-1374.

Tamaoka, J. \& Komagata, K. (1984). Determination of DNA base composition by reverse-phase high-performance liquid chromatography. FEMS Microbiol Lett 25, 125-128.

Wayne, L. G., Brenner, D. J., Colwell, R. R., Grimont, P. A. D., Kandler, O., Krichevsky, M. I., Moore, L. H., Moore, W. E. C., Murray, R. G. E. \& other authors (1987). Report of the Ad-Hoc-Committee on Reconciliation of Approaches to Bacterial Systematics. Int J Syst Bacteriol 37, 463-464.

Weaver, P. F., Wall, J. D. \& Gest, H. (1975). Characterization of Rhodopseudomonas capsulata. Arch Microbiol 105, 207-216.

Yanagi, M. \& Yamasato, K. (1993). Phylogenetic analysis of the family Rhizobiaceae and related bacteria by sequencing of $16 \mathrm{~S}$ rRNA gene using PCR and DNA sequencer. FEMS Microbiol Lett 107, 115-120.

Yoon, J.-H., Kim, H., Kim, S.-B., Kim, H.-J., Kim, W. Y., Lee, S. T., Goodfellow, M. \& Park, Y.-H. (1996). Identification of Saccharomonospora strains by the use of genomic DNA fragments and rRNA gene probes. Int J Syst Bacteriol 46, 502-505.

Ziemke, F., Höfle, M. G., Lalucat, J. \& Rosselló-Mora, R. (1998). Reclassification of Shewanella putrefaciens Owen's genomic group II as Shewanella baltica sp. nov. Int J Syst Bacteriol 48, 179-186. 